\title{
Customer Satisfaction as Intervening Between Use Automatic Teller Machine (ATM), Internet Banking and Quality of Loyalty (Case in Indonesia)
}

\author{
Indrayani ${ }^{1}$, Chablullah Wibisono ${ }^{1}$, Sanni Aritra ${ }^{1} \&$ Iskandar Muda $^{2}$ \\ ${ }^{1}$ Faculty of Economics, Universitas Batam, Riau Islands, Indonesia \\ ${ }^{2}$ Faculty of Economics and Business, Universitas Sumatera Utara, Medan, Indonesia \\ Correspondence: Iskandar Muda, Faculty of Economics and Business, Universitas Sumatera Utara, Medan, \\ Indonesia.
}

Received: June 13, 2019

Accepted: August 10, 2019

Online Published: August 13, 2019

doi:10.5430/ijfr.v10n6p54

URL: https://doi.org/10.5430/ijfr.v10n6p54

\begin{abstract}
This research aims to determine the effect of customer satisfaction as an intervening variable between utilization of Automatic Teller Machine (ATM) variable, Internet Banking variable and service quality variable to variable customer loyalty at PT. Bank Mandiri Tbk in Batam city, Indonesia. This research is collecting the data in the form of primary and secondary data. Collecting the data in this study using questionnaires in the form of respondents Involved in this research were 187 customers. The number is obtained by using the formula Slovin with random sampling. The collected the data were processed and Analyzed by using SPSS and SEM for normality, regression coefficient, and determination. From the result show that the variable utilization ATM, Internet Banking and service quality affect to customer satisfaction has $83 \%$. That is the service quality variables of the most dominant influence on customer satisfaction and customer loyalty.
\end{abstract}

Keywords: automatic teller machine, internet banking, service quality, customer satisfaction, customer loyalty

JEL Code: G21, L86, O14

\section{Introduction}

Providing customer satisfaction is an essential element of the business world. Maintain customer satisfaction over time not just going to build good relationships but also have an impact on the level of profits for the company, so the company can run and widen their business for the future. One form of the company is closely related to banking services. A bank is a financial institution that has a huge role in today's economy. Especially the part of banks as institutions fundraiser and channeling public funds. Bank as one of the financial services sector, its performance is highly dependent on the right and lousy service. The increasingly fierce business competition and the emergence of competitors in the banking business, a bank will strive to create and offer the latest products making it easier for customers to make transactions. On the other hand, in the midst of such a rapid development of technology, there are also people who prefer to make payments using cash. For example, to perform transactions, carried cashier takes quite long even so lengthy process that makes customers not patient enough in a long queue. A lot of customers out of the time activity routine payment of monthly bills such as electricity and water, telephone, credit card, charging pulse, shopping and so forth. As for a customer to queue to check account balances, transfer funds between accounts or between banks, and so on. Use of information technology as an alternative delivery channel in dealing with an infrastructure bank to improve customer satisfaction. Including through the use of Internet Banking service and ATM (Automatic Teller Machine). ATM (Automatic Teller Machine) or in Indonesian called Automated Teller is the most popular Electronic Banking channels are known to the public at large. Customers no longer need to participate in extended queues or deal directly with the bank officers during working hours or outside working hours. ATM included in the system of services provided by banks to customers to be able to do transactions in cash or non-cash. The most commonly performed when transacting at the ATM is making money in stock, transfers between accounts,

Internet Banking is a new banking facility for the moment. The service allows customers to make transactions via the internet using a computer/PC or PDA (Personal Digital Assistant). Features transaction to do the same with the Phone Banking, the information services/products of the bank, account balance information, transaction transfer 
between accounts, payment (such as credit cards, electricity, and telephone), purchasing (such as vouchers and tickets), and transfer to another bank (Avornyo, 2019). The advantages of Internet Banking are the convenience of transacting with the menu display and complete information that is displayed on a computer screen. Including the cost and time savings as well as relatively secure transaction. Accessing it can be done 24 hours a day, seven days a week. Customers can be served at any time; customers can also transact anywhere. Nor has the quality of service shown by the employees of the Bank or the Bank where the loyalty of work became a frequent basis even demanded that the employee's performance result in satisfaction for customers. Commitment is a ticket to success of all companies. A customer satisfaction supports successful strategies oriented supposed to produce loyal clients. That "a loyal customer is a satisfied customer" is a valid statement. However, keep in mind that not all that satisfied customers are loyal customers. It's evident that satisfaction is a primary condition for customer loyalty.

Based on the fact that there was, at the time of use of the ATM made by customers turns out there are transactions of problems such as balance terdebet system (for example, when conducting a transaction flow is interrupted, the client does not receive the most/some money while his account has been debited) and there is a difference more or less restocking (charging money), for example, when performing customer transactions received some money over the cash in the ATMs will be reduced or vice versa so will the differences between the restocking of which it should be, even the occurrence of fraud case ATM cash machine at PT. Bank Mandiri KCPCipto Mangunkusumo (RSCM) in May 2014 ago. Nor has the quality of services provided by PT. Bank Mandiri (Persero) Tbk during a long queue at the teller and another when experiencing complaints resulted in customers do not experience the satisfaction of the transaction so that customers are not loyal to the PT. Bank Mandiri (Persero) Tbk Batam. Based on the description of the background then we propose some issues as follows:

1) Are Automatic Teller Machine (ATM) effect on customer satisfaction at PT. Bank Mandiri Batam?;

2) Is Internet Banking effect on customer satisfaction at PT. Bank Mandiri Batam?;

3) Is the impact of service quality on customer satisfaction at PT. Bank Mandiri Batam?;

4) Are Automatic Teller Machine (ATM), Internet Banking and simultaneously affect service quality on customer satisfaction at PT. Bank Mandiri Batam?;

5) Is the use of Automatic Teller Machine (ATM) effect on customer loyalty at PT. Bank Mandiri Batam?;

6) Is Internet Banking effect on customer loyalty at PT. Bank Mandiri Batam?;

7) Is the impact of service quality on customer loyalty at PT. Bank Mandiri Batam city ?;

8) Are Automatic Teller Machine (ATM), Internet Banking and quality of service simultaneously affect the customer loyalty at PT. Bank Mandiri Batam?;

9) Is the influence of customer satisfaction on customer loyalty at PT. Bank Mandiri Batam?

\section{Literature Review}

\subsection{Automatic Teller Machine (ATM)}

According to Sugiharto (2010) Automatic Teller Machine (ATM) is a cash register that works automatically. Not much different from the principles of the work done by a teller, ATM capable of handling customers in a variety of financial transactions. So we can be sure customers do not need to bother to come to the office to deal with the service or teller each time a sale. According to research conducted Victoria (2013), for using an ATM card required the working process of the ATM. ATM cards are inserted into the machine in the form of oral/container where the money will be read by the magnetic card reader that is inside the device, and then the data is sent to the bank computer system. Then the ATM will ask you to enter a password, i.e., calling a personal identification number or PIN Number-called Personal Identification, its function is to prove that the customer is the owner of the ATM card to verify the data. When the data has been processed in the bank's computer system, the data will be sent back to the ATM to meet customers' needs. Then when the transaction is completed, customers get a receipt or a receipt in the form of paper printed by the ATM to display the nominal amount of money paid as proof of the transaction. No ATM operating system off-line, i.e., machines not connected to a central computer but operates independently and on-line which necessitates an ATM and a computer central communication channel that operates 24 hours continuously. Its function is to prove that the customer is the owner of the ATM card to verify the data. When the data has been processed in the bank's computer system, the data will be sent back to the ATM to meet customers' needs. Then when the transaction is completed, customers get a receipt or a receipt in the form of paper printed by the ATM to display the nominal amount of money paid as proof of the transaction. No ATM operating system off-line, i.e., machines not connected to a central computer but operates independently and on-line which necessitates 
an ATM and a computer central communication channel that operates 24 hours continuously. Its function is to prove that the customer is the owner of the ATM card to verify the data. When the data has been processed in the bank's computer system, the data will be sent back to the ATM to meet customers' needs.

Then when the transaction is completed, customers get a receipt or a receipt in the form of paper printed by the ATM to display the nominal amount of money paid as proof of the transaction. No ATM operating system off-line, i.e., machines not connected to a central computer but operate independently and on-line which necessitates an ATM and a computer primary communication channel that serves 24 hours continuously. Then the data will be sent back to the ATM to meet customers' needs. Then when the transaction is completed, customers get a receipt or a receipt in the form of paper printed by the ATM to display the nominal amount of money paid as proof of the transaction. No ATM operating system off-line, i.e., machines not connected to a central computer but operates independently and on-line which necessitates an ATM and a computer central communication channel that operates 24 hours continuously. Then the data will be sent back to the ATM to meet customers' needs. Then when the transaction is completed, customers get a receipt or a receipt in the form of paper printed by the ATM to display the nominal amount of money paid as proof of the transaction. No ATM operating system off-line, i.e., machines not connected to a central computer but operate independently and on-line which necessitates an ATM and a computer primary communication channel that serves 24 hours continuously.

According to Sutarman, (2009) benefit from the application of information technology, dimensions and indicators are as follows: (1) Speed: is able to grind complex calculations in seconds, very fast, much faster than can be done by human; (2) Consistency: more consistent processing results do not change because of the format (shape) is standard, although done repeatedly, while humans difficult generate precisely the same; (3) Accuracy (Precision): not only faster, but also more accurate and precise (precision). Can detect a very small difference, which can not be seen with the human ability, and also can perform calculations that are difficult; (4) Reliability (Reliability): what is produced is more trustworthy than is done by humans. Errors that occur less likely when using a computer.

\subsection{Internet Banking (IB)}

The Internet is a collection of computer network that connects various kinds of websites, such as educational websites, government, commercial, and financial organizations (Maslan and Wangdra, 2012 and Xie et al., (2019). Internet is a communication tool and gets information from millions of websites that spread throughout the world. Fueled by the growth of the Internet, the increasing capabilities of hardware and software at high speed and spread of computers, more and more aware of the bank's customers will be a variety of convenience gained by the availability of online banking. Internet Banking or also known as online business is a banking facility that allows customers to conduct financial transactions on the web provided by the bank through the internet (Vyctoria, 2013 and Lageson \& Maruna, 2018). According Victoria (2013), as well as other e-banking services, if you want access to sign the internet banking service, a customer should have identification codes (user ID) and PIN (Personal Identification Number). This is required to ensure the safety of customers that each service is provided only used by clients who really has the right when entering into a web service internet banking. Security techniques are often used in internet banking is through SSL (Secure Socket Layer) or via HTTPS (Secure Hypertext Transfer Protocol). Examples contained in PT Bank Bukopin services using protocols Batam city https://ib.bankmandiri.co.id, Web browsers such as Internet Explorer, Chrome, and Firefox displays a lock icon to indicate that the website is secure than displaying https://in the address bar.

According Simarmata (2010) describes the criteria for a quality website then the dimensions and indicators are as follows: (1) Usability: is defined as the user experience in interacting with the app or website to the user to operate it; (2) Navigation: namely how to help people find an easy way when browsing websites; (3) Writing Concept (concept of writing): means reading the text on the screen will be faster than on paper, so the user gets a clear visual message; (4) Simplicity (Simplicity): pure not in the sense of the look of a site, but instead leads to the writing techniques; (5) Accessibility (ease of access): the ease in accessing bring visitors back again (feed back); (6) Color blindness (color blindness): format color blindness affects the use of the website then selecting the right colors required; (7) Graphic (graphic elements): has some essential function in the web site; (8) New technologies: development of the Internet so rapidly create multiple developers to add new technology that can show the required application.

\subsection{Quality of Service}

Quality according to ISO 9000 (Enríquez et al, 2019) is: "a degree to the which a set of inherent characteristics fulfills implied or obligatory" (the degree achieved by the inherent characteristics meet the requirements). The requirements in this regard are: "need or expectation that is stated, generally implied or obligatory" (i.e., the need or expectation that is stated, generally implied or obligatory). So the quality of which is interpreted ISO 9000 is a 
combination of characteristics which determine the extent to which output can meet the requirements of the customer's needs. Customers who specify and assess how far the properties and characteristics that meet their needs (Vafainia et al., 2018). According to research conducted by Suryani (2012) to know the dimensions of service quality further elaborated in detail include:

\section{1) Reliability}

Customers will assess the safety based on the extent of service companies provide a consistent service to the promise. Included in this indicator are consistent services, types of services as offered (Meng \& Zhang, 2018). For example, if the company stated that the opening hours, between the hours of 08:00 to 16:00 pm. The service will be assessed reliably by the customer if every day during working hours consistently at the remains of service. Opened at $08.00 \mathrm{am}$, as already announced and closed at the appointed hour (16:00).

\section{2) Responsiveness}

Customers will assess the quality of service of the bank clerk speed in responding to and following up on complaints submitted by customers.

\section{3) Competence}

Customers will assess the quality of service from the aspect of the power of employees handling customer service (Ali et al., 2018). Capability judged by the ability of officers to master the products and services offered, procedures, work instructions and related policies.

\section{4) Access}

If a service company to provide convenience to customers or members to contact with the company and its employees or attempt to get closer to the customer location. Customers get the ease of getting in touch with the company (Lee, 2018), then the customer will assess obtain comfort in accessing and utilizing services offered. The ease of accessing it will be judged as an essential part of quality service.

\section{5) Courtesy}

Every customer would be pleased if served with courtesy by appropriate manners in society. Therefore, courtesy of employees into one part that was rated by customers and becomes part of the quality of services.

\section{6) Communication skills}

The ability of employees who deal directly with customers to be one of our customers and communities assessment of the quality of services provided. Customers will feel dissatisfaction and poor judgment if when asking for something related to the services offered, the information is incomplete, inaccurate or incorrect or improper communicate way.

\section{7) Credibility}

Credibility is the essential employee who rated by customers. The likelihood associated with factors other than honesty is also associated with things that are psychological that lead to the emergence of trust and customer interest in the services offered.

\section{8) Security}

Security is an essential element to consider customer.

9) Intangible factors and other physical facilities

The location, the condition of the place, the room, the parking lot as well as existing infrastructure becomes a factor in assessing the quality of service.

\subsection{Customer Satisfaction (SAT)}

Customer satisfaction is one of the factors that influence the focus of the company to the customer to achieve the goals and the means of marketing. Companies that take the level of customer satisfaction will have a significant impact on the company's image and company value. In the opinion of Kotler and Keller (2009), customer satisfaction is feeling happy or disappointed someone arising from comparing the perceived performance of the product (or results) against their expectations. If the return in fulfilling the expectations of failure, of course, the customer or the customer is not satisfied. Conversely, if successful then the customer will be happy. Kotler, et al., (2009) identified four methods as indicators to measure customer satisfaction are as follows: 
1. Complaints and Feedback System

Every customer-oriented organization (customer-oriented) need to be providing opportunities and access comfortable and convenient for customers to submit suggestions, criticisms, opinions, and grievances.

2. Ghost Shopping (Mystery Shopping)

One way to obtain an overview of customer satisfaction is to employ some ghost shopper to act or pretend to potential customers the company's products and competitors. They were asked to interact with the staff, and service providers use the company's products or services. Based on these experiences, they were then asked to report its findings regarding the strengths and weaknesses of the company's products and competitors.

3. Lost Consumer Analysis

Wherever possible the company should contact those customers who have stopped buying or who have moved supplier to understand why it happened and to take further policy improvements or enhancements. The not only exit interview is required, but monitoring is also essential customer loss rate, an increase in customer loss rate shows the failure of the company to satisfy customers. Only trouble is the application of this method in identifying and contacting former customers who are willing to provide feedback and evaluation of the performance of the company.

\section{Customer satisfaction survey}

Most of customer satisfaction research conducted using the survey method, both the study by mail, telephone, e-mail, websites, and interviews. Through the survey company will obtain responses and feedback directly from customers and also give a positive impression that companies were paying attention to customers.

\subsection{Customer Loyalty}

According Kotler (2009) states customer loyalty (customer loyalty) is a combination of the customers are likely to purchase from the same supplier in the future and the possibility to buy products or services at various price levels (price tolerance). Based on the dimensions of attitudes and behavior, according to Suchanek \& Kralova (2018) or customer loyalty can be divided into four categories, namely:

\section{1) Captive customers}

Repurchase a brand, product, or service because they had no real choice. They do not have many chances to switch, or may they perceive the cost of changing (changing value) is relatively high (in the form of comfort and funding).

\section{2) Convenience-seeker}

Repurchase or revisit the same store, but the attitude tends to inertia. For him, comfort is the dominant factor pushing choosing a brand, product, or a specific store. The convenience factor can include access convenience (location and time of operation), the package size, reputation (especially if consumers buy something for someone else), and availability.

\section{3) Contented customers}

Having a positive attitude toward a brand, but tend to inertia regarding behavior. They remained a consumer but did not increase its involvement with the brand in question. That is, they do not buy services or ancillary services or buy other products associated with the brand in question.

4) Committed customers

Is the type of consumers who have a positive attitude and behavior towards a specific brand. This type is a valid loyal consumer group. They are willing to expand his business with his favorite brand, to establish long-term relationships with these brands, and deliver definite method mouth to other potential customers. They also tend to overlook the different brand promotion seduction.

Based on these descriptions, the framework of this research can be described in Figure 1 as follows: 


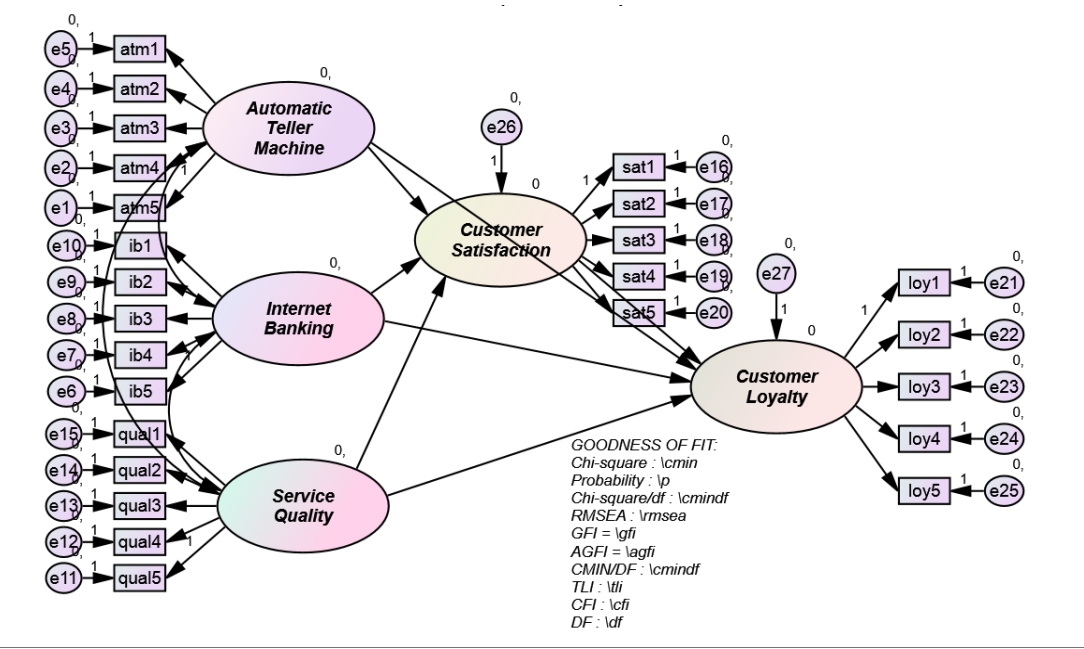

Figure 1. The framework

Based on Figure 1, referring to the problems studied and the purpose of this study, the developed data is data about the factors that influence customer loyalty through customer satisfaction on the role of the use of Automatic Teller Machine (ATM), Internet Banking services and Quality of Service. (E) Customer Loyalty endogenous variables (Z), consists of four indicators, namely: Captive Customers, Convenience-Seekers, Contented Customers and Committed Customers. Referring to the problems studied and the purpose of this study, the developed data is data about the factors that influence customer loyalty through customer satisfaction on the role of the use of Automatic Teller Machine (ATM), Internet Banking services and Quality of Service. (E) Customer Loyalty endogenous variables (Z), consists of four indicators, namely: Captive Customers, Convenience-Seekers, Contented Customers and Committed Customers. Referring to the problems studied and the purpose of this study, the developed data is data about the factors that influence customer loyalty through customer satisfaction on the role of the use of Automatic Teller Machine (ATM), Internet Banking services and Quality of Service.

\section{Research Methods}

\subsection{Location, Object and Time Research}

The research location Branch Office PT. Bank Mandiri (Persero) Tbk Batam city which is located in Riau Islands Mall, Batam Center. The object of research is the customers of PT. Bank Mandiri (Persero) Tbk Batam city that use ATM and Internet Banking.

\subsection{Operational Variables}

The operational variables that become the focus studied in this research, consisting of three exogenous variables and two endogenous variables, namely: (a) variables exogenous ATM $\left(\mathrm{X}_{1}\right)$, consists of four indicators, namely: the velocity (speed), consistency (consistency), accuracy (precision), and reliability (reliability); (B) The variable exogenous Internet Banking $\left(\mathrm{X}_{2}\right)$, consisting of eight indicators, namely: usability, navigation, concept of writing (writing concept), simplicity (simplicity), ease of access (accessibility), color blindness (color blindness), graphic elements (graphic), and new technologies; (C) exogenous variables Quality of Service $\left(\mathrm{X}_{3}\right)$, consisting of nine indicators, namely: Reliability, Responsiveness, Competence, Access, Courtesy, Communication skills, credibility, security and intangible factors and other physical facilities; (D) Customer Satisfaction endogenous variable (Y), consists of four indicators, namely: the system of complaints and suggestions, Ghost Shopping (Mystery Shopping), Lost Consumer Analysis and Customer Satisfaction Survey; (E) Customer Loyalty endogenous variables (Z), consists of four indicators, namely: Captive Customers, Convenience-Seekers, Contented Customers and Committed Customers.

\subsection{Population and Sample}

Population is the region of generalization that occurs from the object or subject in the quantity and specific characteristics defined by the researchers to learn and then drawn conclusions, populations are especially with regard to the data and is the totality of all possible values, both the count and measurement of quantitative and qualitative characteristics the specifics of a complete set of objects (Rumengan, 2015). In this study population is all customers 
who use Automatic Teller Machine (ATM) and Internet Banking PT. Bank Mandiri (Persero) Tbk in Batam city consists of 350 customers. The amount of samples adapted to the analysis model used is Structural Equation Modeling (SEM) that uses the model estimates the maximum likelihood estimation (MLE) is 100-200 samples (Ghozali, 2011), or as much as 5-10 times the number of parameters to be estimated. 350 population, based on a formula Slovin $\mathrm{n}=350 /(1+350 \times 0,052)=186.17$ rounded up to 187 samples.

\subsection{Data Collection Techniques}

Data collection activities using systematic procedures and standards to obtain the necessary data. The data used for exploratory, hypothesis testing and basic materials conclusion of the study (Rumengan, 2015). The data collected in this study were divided into two ways, through field studies and literature. In this research using random sampling techniques with quantitative data. Primary data is data obtained directly from respondents or informants, and secondary data, the authors collected data from various information sources such as books, magazines and other sources of information relating to research problems and went to the branch of PT Bank Mandiri (Persero) Tbk Riau Islands Mall and requested data related to this study. To obtain primary data the researchers used a questionnaire consisting of twenty-five point statement and the number of questionnaires distributed one hundred and eighty-seven according to the number of samples or the respondent. The questionnaire measured using a Likert scale. Likert Scale used to measure attitudes, opinions, and perceptions of respondents about the variables studied. The questionnaire was made with a value of one to five to represent the opinions of the respondents as strongly disagree, disagree, neutral, agree, strongly agree (Umar, 2013). Likert Scale used to measure attitudes, opinions, and perceptions of respondents about the variables studied. The questionnaire was made with a value of one to five to represent the opinions of the respondents as strongly disagree, disagree, neutral, agree, strongly agree (Umar, 2013). Likert Scale used to measure attitudes, opinions, and perceptions of respondents about the variables studied. The questionnaire was made with a value of one to five to represent the opinions of the respondents as strongly disagree, disagree, neutral, agree, strongly agree.

\subsection{Data Analysis}

Data analysis using Structural Equation Modeling (SEM) with AMOS application version 22.0. There are seven steps in modeling SEM, namely:

1) Development of a model based on the theory

2) Development flowchart (Path Diagram)

3) Convert flowcharts to a series of structural equation

4) Selection of the input matrix and the estimation technique on a model built

5) Assess possible problems of identification

6) Evaluation criteria Goddess of Fit

7) Interpretation and modification of the model

Table 1. Evaluation criteria goodness of fit

\begin{tabular}{ll}
\hline Goodness of Fit Index & Cut-off Value \\
\hline X2 - Chi-Square & expected to be small \\
\hline significance Probability & $\geq 0.05$ \\
\hline RMSEA & $\leq 0.08$ \\
\hline GFI & $\geq 0.90$ \\
\hline AGFI & $\geq 0.90$ \\
\hline CMIN / DF & $\leq 3.00$ \\
\hline TLI & $\geq 0.95$ \\
\hline CFI & $\geq 0.95$ \\
\hline
\end{tabular}




\subsection{Calibration Instruments}

\subsubsection{Validity Test}

That the magnitude Corrected, Total Items must be> 0.30. It can be seen that all items of questions variables ATM, Internet Banking, Service Quality, Customer Satisfaction and Customer Loyalty are valid or>0.30 and included in subsequent analyzes.

\subsubsection{Reliability Test}

That the coefficient of Cronbach's Alpha > 0.60. This means that the list of questions contained in the questionnaire is reliable because all variables $>0.60$. Then the list of items in the list of these variables is reliable to measure variables ATM, Internet Banking, Service Quality, Customer Satisfaction and Customer Loyalty. The data is obtained based on the answers of respondents who had been tabulated in advance with Microsoft Excel, as shown in the attachment are then processed with statistical program Amos for Windows version 23, while for normality test, CFA and test the effect of the SEM based on the assumptions in Structural Equation Modeling (SEM) to test the feasibility of the model.

\section{Result and Discussion}

\subsection{Evaluation of Data Normality}

Normality test performed on the data for each indicator latent variables, namely variable data: ATM, Internet Banking, Service Quality, Customer Satisfaction and Customer Loyalty. Based on the results of the Confirmatory Factor Analysis (CFA) program version 22.0 for Windows Amos of research data for each variable latent processing results obtained Amos Assessment of normality in Version 22.0 that there are no indicators of all the variables have to skewness cr> mean $\pm 3,00$. All indicators are normal in terms of skewness and kurtosis there have $\mathrm{cr}$ of $>3.00$. This means that the spread of the data is a normal distribution (not sharp).

\subsection{Analysis Results Goodness of Fit}

Based on the Goodness of Fit test results Table 2 presented as follows:

Table 2. Results of the analysis of goodness of fit

\begin{tabular}{llll}
\hline A goodness of Fit Index & Cut Of Value & Results Model & Information \\
\hline Chi-square (X2) & expected to be small & $\left.490523^{*}\right)$ & Good \\
\hline Relative Chi-square (X2 / df) & $\leq 3,00$ & $\left.1851^{*}\right)$ & Very good \\
\hline probability & $>0.05$ & 0,000 & Not good \\
\hline RMSEA & 0.08 & $\left.0.068^{*}\right)$ & Good \\
\hline GFI & 0.90 & $0,759+)$ & Marginal \\
\hline AGFI & 0.90 & $0,714+)$ & Marginal \\
\hline TLI & 0.95 & $0,843+)$ & Marginal \\
\hline CFI & $>0.95$ & $0,862+)$ & Marginal \\
\hline
\end{tabular}

*) Fulfilling Goodness of Fit

+) Marginal

Table 2 shows that noting the value of Cut-of-Value and Goodness of Fit model results in the table were three criteria were met and four marginal, the poor, of the eight criteria used, then the model above is expressed as a good model (Adi, 2008).

\subsection{Effect Analysis With SEM}

Structural equation model is as follows:

$\mathrm{H} 1: \mathrm{Y}=\gamma \mathrm{y} . \mathrm{X} 1 \mathrm{X} 1+\mathrm{e} 1, \rightarrow$ direct influence (Direct Effects) $\mathrm{X} 1$ to $\mathrm{Y}$,

$\mathrm{H} 2: \mathrm{Y}=\gamma \mathrm{y} . \mathrm{X} 2 \mathrm{X} 2+\mathrm{e} 1, \rightarrow$ direct influence (Direct Effects) $\mathrm{X} 2$ to $\mathrm{Y}$,

$\mathrm{H} 3: \mathrm{Y}=\gamma \mathrm{y} . \mathrm{X} 3 \mathrm{X} 3+\mathrm{e} 1, \rightarrow$ direct influence (Direct Effects) $\mathrm{X} 3$ to $\mathrm{Y}$, 
$\mathrm{H} 4: \mathrm{Y}=\gamma \mathrm{yx} 1 \mathrm{X} 1+\gamma \mathrm{yx} 2 \mathrm{X} 2+\gamma \mathrm{yx} 3 \mathrm{X} 3+\mathrm{e} 1, \rightarrow$ direct influence $\mathrm{X} 1, \mathrm{X} 2, \mathrm{X} 3$ to $\mathrm{Y}$,

$\mathrm{H} 5: \mathrm{Z}=\gamma \mathrm{z} . \mathrm{X} 1 \mathrm{X} 1+\mathrm{e} 2 \rightarrow$ direct influence (Direct Effects) $\mathrm{X} 1$ to $\mathrm{Z}$,

H6: $Z=\gamma$ z.X2 X2 $+\mathrm{e} 2 \rightarrow$ direct influence (Direct Effects) $X 2$ to $Z$,

$\mathrm{H} 7: \mathrm{Z}=\gamma \mathrm{z} . \mathrm{x} 3 \mathrm{X} 3+\mathrm{e} 2 \rightarrow$ direct influence (Direct Effects) $\mathrm{X} 3$ to $\mathrm{Z}$,

$\mathrm{H} 8: \mathrm{Z}=\gamma \mathrm{yx} 1 \mathrm{X} 1+\gamma \mathrm{yx} 2 \mathrm{X} 2+\gamma \mathrm{yx} 3 \mathrm{X} 3+\mathrm{e} 2 \rightarrow$ direct influence $\mathrm{X} 1, \mathrm{X} 2, \mathrm{X} 3$ to $Z$,

H9: $\mathrm{Z}=\beta \mathrm{zy} \mathrm{Y} 1+\mathrm{e} 2 \rightarrow$ direct influence (Direct Effects) $\mathrm{Y}$ to $\mathrm{Z}$

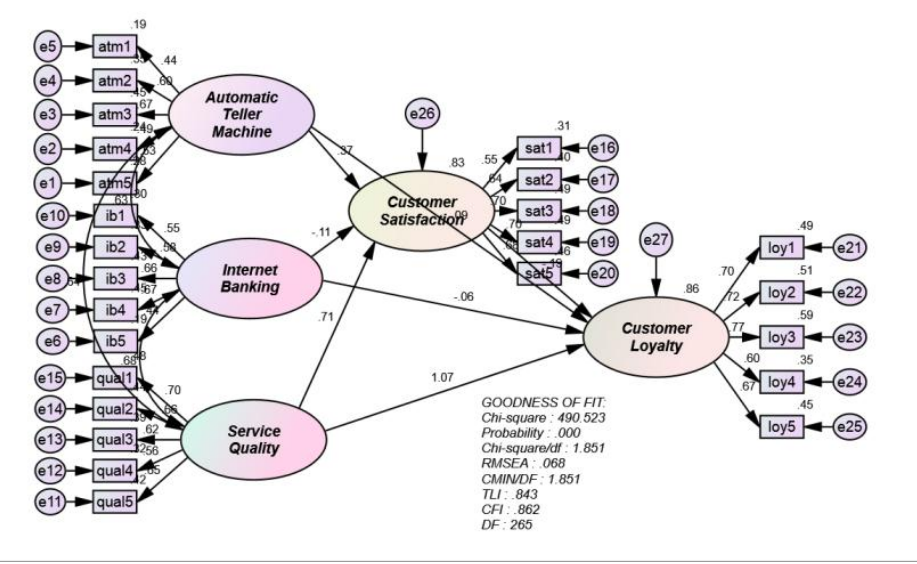

Figure 2. Full model

Figure 2 explained the influence of Automatic Teller Machine (ATM), Internet Banking, Service Quality, Customer Satisfaction and Customer Loyalty variable in. Bank Mandiri (Persero) Tbk Batam. For the Standardized Direct Effects show that in Table 3 as a follows:

Table 3. Standardized direct effects (group number 1 - default model)

\begin{tabular}{llllll}
\hline & ib & ATM & qual & sat & loy \\
\hline sat & -.109 & .371 & .707 & .000 & .000 \\
\hline loy & -.056 & .094 & 1,068 & -.191 & .000 \\
\hline
\end{tabular}

Source: AMOS Result (2017).

Table 3 shows that the variables that have the strongest direct influence are Quality and loyalty. For the Regression Weight show in Table 4 as a follows:

Table 4. Regression weight (Lamda) automatic teller machine (ATM), internet banking (IB), quality of service (QUAL), customer satisfaction (SAT) and customer loyalty (LOY)

\begin{tabular}{|c|c|c|c|c|c|c|c|}
\hline & & & estimate & SE & $\mathrm{CR}$ & $\mathrm{P}$ & Label \\
\hline sat & $<---$ & ATM & .319 & .114 & 2,789 & .005 & par_21 \\
\hline sat & $<---$ & $\mathrm{ib}$ & -.120 & .139 & -.859 & .390 & par_22 \\
\hline sat & $<---$ & qual & .519 & .116 & 4,463 & $* * *$ & par_23 \\
\hline loy & $<---$ & sat & -.287 & .475 & -.603 & .547 & par_24 \\
\hline loy & $<--$ & ATM & .122 & .223 & .545 & .586 & par_25 \\
\hline
\end{tabular}




\begin{tabular}{llllllll}
\hline loy & $<---$ & ib & -.092 & 239 How & -.386 & .699 & par_26 \\
\hline loy & $<---$ & qual & 1,174 & .356 & 3,297 & $* * *$ & par_27
\end{tabular}

Source: The results of the data with AMOS 22, (2017).

In the Table 4 above shows the effects of latent variables Automatic Teller Machine (ATM) against the latent variable Customer Satisfaction (SAT) has standardized estimate regression weight) of 0.371 to $\mathrm{Cr}$ (Critical ratio = identical to the value $t$-test) of 2,789 on probability $=0.005$. CR value 2,789 $>2,00$ and Probability $=0.005<0.05$ indicates that the effect of latent variables Automatic Teller Machine (ATM) against the latent variable Customer Satisfaction (SAT) is a significant positive. For the Regression Standardized Weight (Lamda) Indicator show in Table 5 as a follow:

Table 5. Regression standardized weight (Lamda) indicator automatic teller machine (ATM), internet banking, service quality, customer satisfaction and customer loyalty in Bank Mandiri (Persero) Tbk Batam

\begin{tabular}{llll}
\hline & & \multicolumn{2}{l}{ estimate } \\
\hline sat & $<---$ & ATM & .371 \\
\hline sat & $<---$ & ib & -.109 \\
\hline sat & $<---$ & qual & .707 \\
\hline loy & $<---$ & sat & -.191 \\
\hline loy & $<---$ & ATM & .094 \\
\hline loy & $<---$ & ib & -.056 \\
\hline loy & $<---$ & qual & 1,068
\end{tabular}

Source: The estimation results with AMOS 22, (2017).

Based on the Table 4 and Table 5 show that the compliance with the theory that the use of Automatic Teller Machine (ATM) in a theory supported by the Information Technology equipped with a PIN number so as to facilitate the transaction process more precise, faster, accurate and secure as expected by customers so that customers feel satisfied with the service Automatic Teller Machine (ATM) provided by PT. Bank Mandiri (Persero) Tbk. Batam city. This can be seen on the ground that customers often visit each ATM outlets supplied by the PT. Bank Mandiri (Persero) Tbk. Batam city to perform a variety of transactions and even sometimes a queue is not surprising in one place PT has provided more than one outlet. Bank Mandiri (Persero) Tbk. As a form of satisfaction in creating comfort when going to the transaction. Batam city to perform a variety of transactions and even sometimes a queue is not surprising in one place PT has provided more than one outlet. Bank Mandiri (Persero) Tbk. As a form of satisfaction in creating comfort when going to the transaction. Batam city to perform a variety of transactions and even sometimes a queue is not surprising in one place PT has provided more than one outlet. Bank Mandiri (Persero) Tbk. As a form of satisfaction in creating comfort when going to the transaction. For the analysis of the Measurement Model of Determination show in Table 6 as a follows:

Table 6. Squared multiple correlations: (group number 1 - default model)

\begin{tabular}{ll}
\hline & estimate \\
\hline sat & .830 \\
\hline loy & .860 \\
\hline
\end{tabular}

Source: AMOS Result (2017)

Based on Table 6, the research variables include the Automatic Teller Machine (ATM), Internet Banking; Service Quality has the effect of $83 \%$ on Customer Satisfaction, and Customer Loyalty influence over $86 \%$ is Valid/significant. 
The effects of latent variables Internet Banking (IB) of the potential variable Customer Satisfaction (SAT) has the standardized estimate (regression weight) of -0.109 , with $\mathrm{Cr}$ (Critical ratio $=$ identical to the value $\mathrm{t}$-test) of -0.923 on probability $=-0.859$. $-0.859 \mathrm{CR}$ value $<2.000$ and Probability $=0.390>0.05$ indicates that the effect of latent variables Internet Banking (IB) of the potential variable Customer Satisfaction (SAT) is not significant negatives. Not all customer transactions through Internet Banking due to lack of knowledge or understanding of the use of the service despite being supported by new technologies, so that customer satisfaction is not met. It is seen by investigators when observation is often found on the ground that customers are happy to make transactions directly to the office of PT. Latent variable effects Quality of Service (QUAL) of the latent variable Customer Satisfaction (SAT) has the standardized estimate (regression weight) of 0.707 to $\mathrm{Cr}$ (Critical ratio = identical to the value t-test) of 4.463 on a probability $=* * * . \mathrm{CR}=0.707<2.000$ and Probability $=* * *<0.05$ indicates that the effect of latent variables Quality of Service (QUAL) of the latent variable Customer Satisfaction (SAT) is a significant positive. The findings according to the theory that the service quality is the most important thing in improving customer satisfaction when serving customers, i.e., employees of PT. Bank Mandiri (Persero) Tbk. Batam city is responsive to any customer complaints so that customers feel first and satisfied with the services provided. This situation is by the observations made by researchers that every customer who comes to the office of PT. Bank Mandiri (Persero) will soon be welcomed when officers of PT will open the entrance Bank Mandiri (Persero) Tbk. Then the customer will be given the same greeting to be asked whether the type of service or transaction that the customer wants. Furthermore, customers will be directed to the officer or other employees who are ready to provide the desired service customers.

In the above table potential variable effect Customer Satisfaction (SAT) against the Customer Loyalty, latent variables (LOY) has the standardized estimate (regression weight) of -0.191 with $\mathrm{Cr}$ (Critical ratio = identical to the value t-test) of -0.603 on probability $=0.547$. $\mathrm{CR}=-0.603<2.000$ and Probability $=0.547>0.05$ indicates that the effect of latent variables Customer Satisfaction (SAT) against the Customer Loyalty latent variables (LOY) is not significant negatives. This shows that there is always a sense of satisfaction experienced by customers into loyal customers make every product offered by PT. Bank Mandiri (Persero) Tbk. Batam city. Observations conducted by researchers in the field are when customers are offered use of insurance products of AXA Mandiri. When the offerings provided by employees of PT. Bank Mandiri (Persero) Tbk often refused because the customer is not necessarily as required by the customer. Then, many also found that when customers of PT. Bank Mandiri (Persero) Tbk need a loan for the mortgage process; customers prefer to make loans to other banks because of the complicated terms or conditions that apply.

Latent variables influence Internet Banking (IB) of the Customer Loyalty latent variables (LOY) has the standardized estimate (regression weight) of -0.056 , with $\mathrm{Cr}$ (Critical ratio $=$ identical to the value $\mathrm{t}$-test $)$ of -0.386 on probability $=$ 0.699. $-0.386 \mathrm{CR}$ value $<2.000$ and Probability $=0.699>0.05$ indicates that the effect of latent variables Internet Banking (IB) of the Customer Loyalty latent variables (LOY) is not significant negatives. This shows that the Internet Banking services are used by customers not create loyal customers for using additional products supplied or provided by PT. Bank Mandiri (Persero) Tbk. Batam city. Naturally when observations in the field found that customers of PT. Bank Mandiri (Persero) Tbk more visits existing ATM booth and come to the office because the evidence is credible direct transaction receipts obtained through transfers made in outlets ATM or deposit slip or removal were accomplished when trading the offices of PT. Bank Mandiri (Persero) Tbk Batam.

In the three table above shows the effects of latent variables Quality of Service (QUAL) of the Customer Loyalty latent variables (LOY) has standardized regression weight estimate) of 1.068 with $\mathrm{Cr}$ (Critical ratio $=$ identical to the value t-test) of 3.297 on a probability $=* * *$. CR value 3.297> 2.00 and Probability $=* * *<0.05$ indicates that the effect of latent variables Quality of Service (QUAL) of the Customer Loyalty latent variables (LOY) is significantly positive. The findings according to the theory which says that the quality of service makes customers want to tell method definite mouth and recommend it to other customers. High credibility, affordable ATM locations, airport employees as expected and others are mostly things that support customer loyalty. This phenomenon is seen by investigators when the observation in a shopping center or at each outlet ATM at a gas station that when customers of other banks run into trouble when trying to make payments and transactions such as ATM the other banks being offline, the customer is immediately moved to booth ATM PT. PT Bank Mandiri customers. The Bank completed the purchase and said that the ATM could be enabled. Then mostly found in the shopping center when customers want to pay using debit cards of other banks, then the cashier recommends debit provided is EDC (Electronic Data Capture) PT. Bank Mandiri (Persero) Tbk. Also, many customers of PT. Bank Mandiri (Persero) who feel the satisfaction of service to establish long-term relationships with cooperating to the PT.

The effects of latent variables Automatic Teller Machine (ATM) against the Customer Loyalty latent variables (LOY) has the standardized estimate (regression weight) of 0.094, with $\mathrm{Cr}$ (Critical ratio = identical to the value t-test) of 0.545 on a probability $=0.586$. CR value $0.545<2.000$ and Probability $=0.586>0.05$ indicates that the effect of latent 
variables Automatic Teller Machine (ATM) against the Customer Loyalty latent variables (LOY) is positive, not significant. These results indicate that customers of PT. Bank Mandiri (Persero) Tbk happy to make transactions through the ATM but do not want to be in to show a sense of loyalty to customers. Researchers noticed that most customers of PT. Bank Mandiri (Persero) Tbk Batam is an employee in a private company in cooperation with PT. Bank Mandiri (Persero) Tbk Batam. The more employees use ATMs because their salaries paid directly to private companies Mandiri their account. It is no wonder that many found although customers of PT. Bank Mandiri (Persero) Tbk disloyal in using another product of PT. Bank Mandiri (Persero) Tbk Batam.

\section{Conclusions}

\subsection{Conclusion and Recommendations}

1. The use of Automatic Teller Machine (ATM) effect on customer satisfaction verified.

2. Internet Banking effect on customer satisfaction is not verified.

3. Quality of Service effect on customer satisfaction verified.

4. The use of Automatic Teller Machine (ATM), Internet Banking and simultaneously affect service quality on customer satisfaction verified.

5. The use of Automatic Teller Machine (ATM) effect on customer loyalty is not verified, is not significant.

6. Internet Banking effect on customer loyalty is not verified, is not significant.

7. Quality of Service effect on customer loyalty verified, significantly.

8. The use of Automatic Teller Machine (ATM), Internet Banking and simultaneously influence the quality of customer satisfaction verified, significantly.

9. Customer satisfaction effect on customer loyalty is not verified, is not significant.

\subsection{Suggestion}

1. To PT. Bank Mandiri (Persero) Tbk. Batam city to be able to use equations Structural Equation Model (SEM) This in analyzing problems of Automatic Teller Machine (ATM), Internet Banking and Service Quality related to Customer Satisfaction and Customer Loyalty.

2. It is expected to expand its facilities and the existing equipment and follow the progress of information technology increasingly sophisticated security systems supported by the use of the service given to the use of the ATM.

3. Untuk attention to Internet Banking services so that customers are more interested in using it in daily transaction activity. For example, campaigns in schools, offices, and others to improve the customers to use the Internet Banking service.

4. Case things in improving the quality of service to resolve any complaints or customer demand that is when customers are confused when choosing the type of transaction what is needed, when customers experience debited account without performed by the customer, or when clients ask for advice on the needs of the sale it is expected that employees of PT. Bank Mandiri provides workable solutions.

5. Need to install a reliable and sophisticated technology to determine any ATM outlets in sure radar quickly is in trouble and immediately improve the situation or problems encountered by PT. Mandiri Bank.

6. PT. Bank Mandiri (Persero) Tbk. Batam city suggested giving lucrative offers, for example, the provision of an attractive gift or gifts that customers are interested in using Internet Banking so that customers more loyal to using the Internet Banking service.

7. Be expected improve the quality of existing services so that customers feel the positive things that are different from other bank services. This can be done with the attitude and behavior of employees of PT. Bank Mandiri (Persero) Tbk Batam city as well as showing high credibility.

8. Expected PT. Bank Mandiri (Persero) Tbk. Batam city to build long-term relationships with every customer who wants to join in the products and the business has to offer. Whether it is insurance products, short-term loans, long-term loans and simplify the mortgage process when the customer needs it.

9. Expected next to researchers to add the variables that exist, eg, security system variable, the variable comfort, lifestyle variables, etc. to develop this research. 


\section{References}

Ali, F., Kim, W. G., Li, J., \& Jeon, H. M. (2018). Make it delightful: Customers' experience, satisfaction and loyalty in Malaysian theme parks. Journal of Destination Marketing \& Management, 7(1), 1-11. https://doi.org/10.1016/j.jdmm.2016.05.003

Astutik, S. (2019). Supervision of the Financial Service Authority of Sharia Compliance as the Protection of Depositors. Revista Publicando, 6(19), 244-251.

Avornyo, P. (2019). Are customers still with us? The influence of optimum stimulation level and IT-specific traits on mobile banking discontinuous usage intentions. Journal of Retailing and Consumer Services, 47(1), 348-360. https://doi.org/10.1016/j.jretconser.2019.01.001

Enríquez, J. G., Sánchez-Begines, J. M., Domínguez-Mayo, F. J., García-García, J. A., \& Escalona, M. J. (2019). An approach to characterize and evaluate the quality of Product Lifecycle Management Software Systems. Computer Standards \& Interfaces, 61(2), 77-88. https://doi.org/10.1016/j.csi.2018.05.003

Ghozali, I. (2011). Structural Equation Modeling Concepts and Applications with AMOS Program 22.0. Semarang: Diponegoro University Publishers Agency.

Koo, M., Kang, H. S., \& Ham, S. (2018). Customers' Purchase Patterns and Expectation-Confirmation toward Home Meal Replacement Products. Journal of the Korean Dietetic Association, 24(3), 246-260.

Kotler, P. T., \& Keller, K. L. (2009). Marketing Management (13th ed.). Jakarta: Erlangga Publisher.

Lageson, S. E., \& Maruna, S. (2018). Digital degradation: Stigma management in the internet age. Punishment \& Society, 20(1), 113-133. https://doi.org/10.1177/1462474517737050

Lee, S. (2018). Enhancing customers' continued mobile app use in the service industry. Journal of Services Marketing, 32(6), 680-691. https://doi.org/10.1108/JSM-01-2017-0015

Meng, C., \& Zhang, S. (2018). Influence of characteristics of online sporting goods store on customers' purchase intention based on TAM: Taking Dachuan Pingpong as an example. Journal of Shandong Sport University, 13(3), 73-89.

News, M. (2014). Crowded Block Account. Retrieved December 17, 2017, from Metro.news.viva.co.id/news/read/503740-nasabah-bank-mandiri-rscm-ramaicrowded-block-account

Omar, H. (2013). Thesis and Research Methods for Business Thesis (2nd ed.). Jakarta: King Grafindo Persada.

Rumengan, J. (2015). Quantitative Research Methodology (1st ed.). Terrain: Publisher Prime Publishing.

Simarmata, J. (2010). Engineering Web. Yogyakarta: Andi Publishers.

Suchanek, P., \& Kralova, M. (2018). The Influence of Customers'personal Characteristics On Their Satisfaction With The Food Industry. Journal of Competitiveness, 10(4), 151-170. https://doi.org/10.7441/joc.2018.04.10

Sugiyono. (2008). Business Research Methods. Bandung: Alfabeta Publishers.

Suryani, T. (2012). Implications of Consumer Behavior Marketing Strategy (1st ed.). Yogyakarta: Graha Science Publishers.

Sutarman. (2009). Introduction to Information Technology Systems. Jakarta: Earth Literacy.

Vafainia, S., Breugelmans, E., \& Bijmolt, T. (2019). Calling Customers to Take Action: The Impact of Incentive and Customer Characteristics on Direct Mailing Effectiveness. Journal of Interactive Marketing, 45, 62-80. https://doi.org/10.1016/j.intmar.2018.11.003

Vyctoria. (2013). Unloading Secrets E-Banking Security with Hacking Techniques and Carding. Yogyakarta: Andi Publishers.

Wang, A., Chang, W., Chen, S., \& Mohaisen, A. (2018). Delving into internet DDoS attacks by botnets: characterization and analysis. IEEE/ACM Transactions on Networking, 26(6), 2843-2855. https://doi.org/10.1109/TNET.2018.2874896

Xie, X. F., Xie, X. M., \& Martínez-Climent, C. (2019). Identifying the factors determining the entrepreneurial ecosystem of internet cultural industries in emerging economies. International Entrepreneurship and Management Journal, 1-20. https://doi.org/10.1007/s11365-019-00562-z 